\title{
Evapotranspiration from a Mediterranean evergreen oak savannah: The role of trees and pasture
}

\author{
Teresa A. Paço ${ }^{\mathrm{a}, *}$, Teresa S. David ${ }^{\mathrm{b}}$, Manuel O. Henriques ${ }^{\mathrm{a}}$, João S. Pereira ${ }^{\mathrm{a}}$, Fernanda Valente ${ }^{\mathrm{a}}$, \\ João Banza ${ }^{a}$, Fernando L. Pereira ${ }^{c}$, Clara Pinto $^{b}$, Jorge S. David ${ }^{a}$ \\ ${ }^{a}$ Forest Research Center - CEF, Instituto Superior de Agronomia - ISA, Technical University of Lisbon, Tapada da Ajuda, $1349-017$ Lisbon, Portugal \\ ${ }^{\mathrm{b}}$ Instituto Nacional de Recursos Biológicos - INRB, I.P., Quinta do Marquês, 2780-159 Oeiras, Portugal

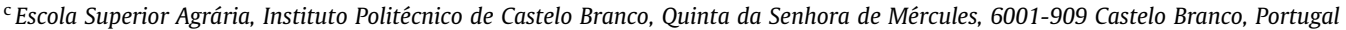

\section{A R T I C L E I N F O}

\section{Article history:}

Received 3 April 2008

Received in revised form 5 February 2009

Accepted 9 February 2009

This manuscript was handled by K. Georgakakos, Editor-in-Chief, with the assistance of Joan G. Ehrenfield, Associate Editor

\section{Keywords:}

Ecohydrology

Eddy covariance

Grassland

Oak woodland

Quercus ilex

Transpiration

\begin{abstract}
S U M M A R Y
Mediterranean evergreen oak woodlands of southern Portugal (montados) are savannah-type ecosystems with a widely sparse tree cover, over extensive grassland. Therefore, ecosystem water fluxes derive from two quite differentiated sources: the trees and the pasture. Partitioning of fluxes according to these different sources is necessary to quantify overall ecosystem water losses as well as to improve knowledge on its functional behaviour. In southern Iberia, these woodlands are subjected to recurrent droughts. Therefore, reaction/resilience to water stress becomes an essential feature of vegetation on these ecosystems. Long-term tree transpiration was recorded for 6 years from a sample of holm oak (Quercus ilex ssp. rotundifolia) trees, using the Granier sap flow method. Ecosystem transpiration was measured by the eddy covariance technique for an 11-month period (February to December 2005), partly coincident with a drought year. Pasture transpiration was estimated as the difference between ecosystem (eddy covariance) and tree (sap flow) transpiration. Pasture transpiration stopped during the summer, when the surface soil dried up. In the other seasons, pasture transpiration showed a strong dependence on rainfall occurrence and on top soil water. Conversely, trees were able to maintain transpiration throughout the summer due to the deep root access to groundwater. $Q$. ilex trees showed a high resilience to both seasonal and annual drought. Tree transpiration represented more than half of ecosystem transpiration, in spite of the low tree density (30 trees ha ${ }^{-1}$ ) and crown cover fraction (21\%). Tree evapotranspiration was dominated by transpiration (76\%), and interception loss represented only $24 \%$ of overall tree evaporation.
\end{abstract}

(c) 2009 Elsevier B.V. All rights reserved.

\section{Introduction}

Mediterranean evergreen oak woodlands, called montados in Portugal and dehesas in Spain, represent 33\% of the total Portuguese forested area. They have a sparse tree cover, over native grassland (or a dryland grown pasture) that recurrently develops into a shrubland. They are mainly located in areas of southern Portugal and Spain with a Mediterranean climate. In these areas, evaporative demand is higher than annual rainfall and the dry season (summer) lasts for several months. Natural droughts are recurrent. Drought severity is increasing and can be further aggravated due to climate change and human action (Isendahl and Schmidt, 2006; Miranda et al., 2006). Therefore, the response of these Mediterranean oak woodlands to water stress is an important issue. Also, the quantification of evapotranspiration from these ecosystems is critical for a correct evaluation of the scarce local water resources.

\footnotetext{
* Corresponding author. Tel.: +351 213653335; fax: +351 213621575.

E-mail address: tapaco@isa.utl.pt (T.A. Paço).
}

However, this is not a simple task since these are savannah-type ecosystems composed by two quite different plant life forms: the trees and the grassland (Joffre and Rambal, 1993; Baldocchi et al., 2004; Baldocchi and Xu, 2007). Therefore, the whole ecosystem cannot be considered as a single, spatially uniform layer for carbon or water vapour exchange with the atmosphere. A two-source approach will certainly be more appropriated. Furthermore, the different life forms are quite variable regarding water use, with deep rooted evergreen trees and shallow rooted malacophyllous shrubs and annual grasses. Tackling changes in water use by two layered ecosystems may increase in complexity as the plant functional type diversity increases due to differences in phenology and rooting depth of plant species (Pereira et al., 2006). The partitioning of ecosystem evapotranspiration between plant life forms and according to different sources is necessary to quantify and model the overall ecosystem water losses as well as to improve the understanding on its functional behaviour.

Partitioning of ecosystem fluxes have been attempted in other studies, whether for carbon dioxide (e.g., Baldocchi and Vogel, 
1996; Kelliher et al., 1999; Law et al., 2001; Falk et al., 2005), water (e.g., Brunel et al., 1997; Baldocchi et al., 2000, 2004; Williams et al., 2004; Lauenroth and Bradford, 2006; Scott et al., 2006) or both (e.g., Constantin et al., 1999; Lamaud et al., 2001; Wilson and Meyers, 2001). Water flux partitioning can be addressed by several approaches, although most frequently the eddy covariance technique is involved as a direct way of estimating evapotranspiration at the ecosystem level. In woody stands, the eddy covariance technique may be combined with tree sap flow measurements to separately estimate tree and ecosystem evaporation (e.g., Köstner et al., 1992; Hutley et al., 2001; Mackay et al., 2002; Silva et al., 2008). Understorey evaporation can be estimated from the difference between eddy covariance and sapflow measurements or directly measured. Direct assessment of understorey evaporation is sometimes done by the eddy covariance or exchange chamber techniques (e.g., Daudet, 1987; Loustau and Cochard, 1991; Améglio et al., 1993). The use of the eddy covariance method below tree canopy may not respect its theoretical assumptions (Misson et al., 2007), but some authors showed that it can be used after a thorough validation of measurements (e.g. Baldocchi et al., 2000; Lamaud et al., 2001; Wilson and Meyers, 2001).

This work aims at a better understanding of evapotranspiration from a Quercus ilex (holm oak) savannah-type ecosystem (montado), by studying the contribution of its two components: the trees and the herbaceous vegetation. Tree transpiration was measured continuously for 6 years (2001-2006) using a sap flow method (Granier method). These data allowed the analysis of inter-annual variation of tree transpiration, including extreme drought conditions. Indeed, during the measuring period an extremely severe drought occurred in 2004 and 2005. This was the most severe drought in the last 60 years in terms of affected land area (EEA, 2007). Eddy covariance measurements at the ecosystem level were carried out in 2005 (11-month period). The herbaceous transpiration was estimated for that period as the simple difference between ecosystem transpiration (eddy covariance) and tree transpiration (sap flow).

Tree canopies always intercept a substantial proportion of the rainfall which is either evaporated - interception loss - or reaches the ground as stemflow or throughfall (Ward and Robinson, 2000). Interception loss is usually an important component of tree evapotranspiration since, under similar weather conditions (radiation and vapour pressure deficit), evaporation rate from a wet tree canopy is much higher than the corresponding transpiration rate, due to a very low aerodynamic resistance (Rutter, 1975; David et al., 2005). In short vegetation, the aerodynamic resistance is one order of magnitude higher than in forests and the evaporation rate from wet leaves is about the same of transpiration rate for similar radiation and humidity (Rutter, 1975; David et al., 2005). This is why the evaporation of intercepted rainfall is a net loss in trees, but not so in short vegetation. Therefore, interception loss was only considered for the tree component of the studied ecosystem, being evaluated through the tree-based adaptation of Gash's analytical model described by Pereira et al. (2009a).

\section{Materials and methods}

\section{The experimental site and meteorology}

The experimental site is a sparse, savannah-type evergreen holm oak (Q. ilex ssp. rotundifolia Lam.) montado, located at Herdade da Alfarrobeira, near Évora, Portugal, hereafter referred to as Mitra II $\left(38^{\circ} 32^{\prime} \mathrm{N}, 8^{\circ} 00^{\prime} \mathrm{W}, 256 \mathrm{~m}\right.$ a.s.l. $)$. Site topography is slightly undulating. The climate is Mediterranean, with mild, wet winters and hot, dry summers. Long-term average annual rainfall is around $669 \mathrm{~mm}$ and mean air temperature around $15^{\circ} \mathrm{C}$. Mean stand den- sity is around 30 trees ha $^{-1}$ and tree crown cover about 21\% (Carreiras et al. 2006). The trees have mean trunk diameter at breast height, crown projected area and height of $0.34( \pm 0.17) \mathrm{m}, 69 \mathrm{~m}^{2}$ and $8 \mathrm{~m}$, respectively. The short vegetation between and beneath the trees is a natural pasture composed mainly of annual gramineae (such as Vulpia bromoides (L.) S.F. Gray and Avena barbata Link), legumes (such as Ornithopus compressus L. and Trifolium subterraneum L.) and forbs (such as Tuberaria guttata (L.) Fourr), with a few intermingled shrubs (mainly Cistus salviifolius, L.). The soil is a ca. $1 \mathrm{~m}$ deep Dystric Cambisol (FAO, 1988), overlying granite bedrock.

Meteorological measurements were performed at the site throughout the experimental period (2001-2006). Wind speed (anemometer A100R, Vector Instruments, Rhyl, UK) and direction (wind vane W200P, Vector Instruments, Rhyl, UK), air temperature and humidity (aspirated psychrometer H301, Vector Instruments, Rhyl, UK), solar radiation (CM6B, Kipp and Zonen, Delft, The Netherlands) and net radiation (Q7, REBS, Seattle, USA) were measured at the top of a 28-m-high tower (about $20 \mathrm{~m}$ above tree canopy). Rainfall was measured at ground level with a tipping-bucket rain gauge (ARG100, Environmental Measurements, Gateshead, UK). Data were stored in a CR10X data logger (Campbell Scientific, Shepshed, UK) at 10-min intervals.

\section{Sap flow measurements}

Sap flow was measured in four Q. ilex trees from 2001 to 2006, using the Granier method (Granier, 1985, 1987) in order to estimate tree transpiration. Mean diameter at breast height $(D B H)$ of sampled trees was $0.38 \mathrm{~m}$. These trees were randomly selected from a larger group $(n=20)$ with mean $D B H$ of $0.34( \pm 0.17) \mathrm{m}$. One sap flow sensor ( $2 \mathrm{~cm}$ long) was installed in the south-facing xylem of each sampled tree. Sap flow sensors were replaced only in case of disruption, since it has been shown that probes do not deteriorate with time and are reliable for long-term measurements in this species (David et al., 2004). Sapwood conductive thickness was estimated from the sap flow radial profile obtained by the heat field deformation method (Nadezhdina et al., 1998) in two Q. ilex trees. Tree sap flow was calculated as the product of sap flow density (measured by the Granier probes) and sapwood conductive area. Average sap flow of the oak stand was estimated as the mean of the four sampled trees. For further details of sap flow measurements and assumptions see David et al. (2007). Sap flow data were integrated on a daily basis and considered equal to tree transpiration at this time-scale. Tree transpiration was expressed in $\mathrm{mm}$ day $^{-1}$ per unit of crown projected area. For comparisons with total ecosystem transpiration (eddy covariance data), transpiration values on a crown area basis were converted into a ground area basis, in $\mathrm{mm} \mathrm{day}^{-1}$, multiplying by the tree crown cover fraction $(0.21)$.

\section{Tree canopy conductance}

Sap flow measurements (per unit of crown projected area) were used to derive midday tree canopy conductance $\left(g_{c}\right)$, using the approximation of McNaughton and Jarvis (1983) and Jarvis and McNaughton (1986) for vegetation highly-coupled to the atmosphere (see David et al., 2007):

$T_{t}=g_{c} D_{e} \frac{\rho c_{p}}{\lambda \gamma}$

where $T_{t}$ is tree transpiration ( $\mathrm{kg} \mathrm{m}^{-2} \mathrm{~s}^{-1}$ ), $g_{c}$ is canopy conductance $\left(\mathrm{m} \mathrm{s}^{-1}\right), D_{e}$ is the vapour pressure deficit of the air $(\mathrm{Pa}), \lambda$ is latent heat of evaporation of water $\left(\mathrm{J} \mathrm{kg}^{-1}\right), \gamma$ is the psychrometric constant $\left(\mathrm{Pa}{ }^{\circ} \mathrm{C}^{-1}\right), \rho$ is the density of air $\left(\mathrm{kg} \mathrm{m}^{-3}\right)$ and $c_{p}$ is the heat capacity of water in air $\left(\mathrm{J} \mathrm{kg}^{-1}{ }^{\circ} \mathrm{C}^{-1}\right)$. Midday canopy conductance 
was calculated during selected months of the drying-up season (April, June, August and October) of the driest (2005) and the wettest (2001) years of the recording period. Days with rainfall were discarded and $g_{c}$ values were expressed in $\mathrm{mm} \mathrm{s}^{-1}$, per unit of crown projected area.

The sensitivity of $g_{c}$ response to $D_{e}$ was studied using the approach developed by Oren et al. (1999) using the equation:

$g_{c}=b-m \ln D_{e}$

where the parameters $m$ and $b$ are generated by least-square regression analysis. The parameter $m$ quantifies the sensitivity of $g_{c}\left(\mathrm{~mm} \mathrm{~s}^{-1}\right)$ to $D_{e}(\mathrm{kPa})$ and $b$ is a reference conductance at $D_{e}=$ $1 \mathrm{kPa}$. Theoretically, the ratio $\mathrm{m} / \mathrm{b}$ will approach 0.6 as long as stomata are regulating efficiently leaf water potential towards a constant value. If the ratio drops below that value, there is a lack of response of stomata to changes in leaf water potential and some degree of xylem cavitation occurs (Oren et al., 1999).

\section{Groundwater table}

The depth of water table was monitored from 2002 to 2005 in a 20-m-deep borehole by a pressure transducer (PDCR 830, Campbell Scientific, Shepshed, UK). The pressure transducer measures the difference in pressure between the atmosphere and that at the depth of the sensor. Since this type of sensor only measures accurately water heights up to $3.60 \mathrm{~m}$, its position was changed periodically to cover the all annual range of water table level variation. Usually two positions per year were enough: one at about $3.5 \mathrm{~m}$ below soil surface during the wet season (from late autumn to early spring) and another at about $6 \mathrm{~m}$ depth during the remainder of the year (dry season). The borehole was dug down near the sampled $Q$. ilex trees. Data were stored at 10 -min intervals in a CR10X data logger.

\section{Rainfall interception loss from trees}

Interception loss from $Q$. ilex trees was estimated using a treebased adaptation of the Gash analytical model, as described by Pereira et al. (2009a). The crown of each isolated tree was considered as a closed canopy and interception loss calculated on a crown area basis. In this case we could use either the revised, sparse (Gash et al., 1995), or the original version (Gash, 1979) of the Gash model, since they are almost equivalent when canopy cover $(c)$ is $100 \%$ $(c=1)$. The use of the sparse version was, however, preferred since its formulation is free from some of the conceptual errors of the original version (Valente et al., 1997).

The Gash model assumes that rainfall is a succession of discrete events, with sufficient time between them for the canopy and trunks to dry-up completely. The canopy and trunks are described by a set of structural parameters, such as the canopy storage capacity $(S)$ and the canopy cover fraction $(c)$. The actual rates of rainfall and maximum possible evaporation are replaced by average values of these variables ( $\bar{R}$ and $\bar{E}$, respectively). We used two of the model parameters derived by Pereira et al. (2009a,b) for Q. ilex trees: crown storage capacity $(S=1.16 \mathrm{~mm})$ and average evaporation rate during saturated conditions $\left(\bar{E}=0.27 \mathrm{~mm} \mathrm{~h}^{-1}\right)$. Average hourly rainfall rate $\bar{R}$ was calculated from all hours when rainfall exceeded a certain threshold $(0.4 \mathrm{~mm})$, following the procedure used by Gash (1979) and Pereira et al. (2009a): $\bar{R}=1.82 \mathrm{~mm} \mathrm{~h}^{-1}$.

The model was successfully tested against measurements in $Q$. ilex trees by Pereira et al. (2009a): modelling estimates were within an error band of $9 \%$ from observations.

Model calculations are performed hourly but integration of final output is done daily: rain that falls on a day is assumed as a single storm. Further details on the modelling conceptual background, parameter derivation and modelling performance are given by Pereira et al. (2009a,b).

\section{Eddy covariance measurements}

Eddy covariance measurements of latent and sensible heat were performed from February to December 2005, using an ultrasonic anemometer (Solent R3 Gill Instruments, Ltd., Hampshire, UK) and a closed-path IRGA (LI-7000 LI-COR, Lincoln, Nebraska, USA). The instruments were placed above the top of the metallic tower, at a height of $29 \mathrm{~m}$, as described in Pereira et al. (2007). A combined footprint and quality assessment analysis was performed under different stability conditions, as described in Göckede et al. (2004, 2008). According to the Göckede et al. (2008) assessment criteria, data quality for latent heat flux was moderate and the fetch conditions were perfect (the measured flux had an average flux contribution from the target area of 99\%). Methods used in flux data processing and computation are described in more detail by Pereira et al. (2007). Data collected during rain were considered unreliable.

Water flux measurements were used to assess total ecosystem transpiration, discarding rainy days (thus excluding days with rainfall interception) and considering soil evaporation negligible. The assumption of negligible soil evaporation is supported on three main reasons: (a) the typically small number of rainfall events that characterize local climate: long-term average (1951-1980) of rain days per year is 85 (INMG, 1991); (b) the sandy nature of the surface soil, with a very low water retention capacity; and (c) the shelter effect of short vegetation during the wet season on radiation and wind speed.

Transpiration data was stored in a PC at half-hourly intervals and integrated on a daily basis. Daily transpiration was expressed in $\mathrm{mm} \mathrm{day}^{-1}$, per unit of ground area.

\section{Transpiration from pasture}

Daily pasture transpiration was estimated as the difference between total daily ecosystem transpiration (eddy covariance) and daily tree transpiration (sap flow). All variables were expressed on the same reference area basis: per unit of ground area. Calculations were performed only for rainless days, during 2005, when eddy covariance data were available.

\section{Results and discussion}

\section{Long-term tree transpiration}

Fig. 1 shows the long-term trend of daily tree transpiration measured by sap flow, along with solar radiation (A), groundwater table depth (B) and rainfall (C and D), for the 2001-2006 period. Annual rainfall was higher than the long-term average (19611990, $669 \mathrm{~mm}$ ) in 2001, 2002, 2003 and 2006 and lower in 2004 and 2005 (Fig. 1D). The wettest year of the record was 2001 and the driest 2005. A 2-year drought period occurred during 2004 and 2005, with the peak of drought severity in the second year. Annual rainfall in 2004 and 2005 was only 73\% and 64\% of the longterm local average, respectively (Fig. 1D and Fig. 2) and winter rainfall in 2005 was only $12 \%$ of the long-term mean. During normal or wet years (2001-2003 and 2006), transpiration showed a trend following closely radiation till the end of spring, when a maximum occurred (this maximum was reached by the middle of June, in all years) (Fig. 1A). After that, transpiration became offset behind the radiation trend, showing a progressive decrease during the summer and a recovery upon the onset of autumn rains. 

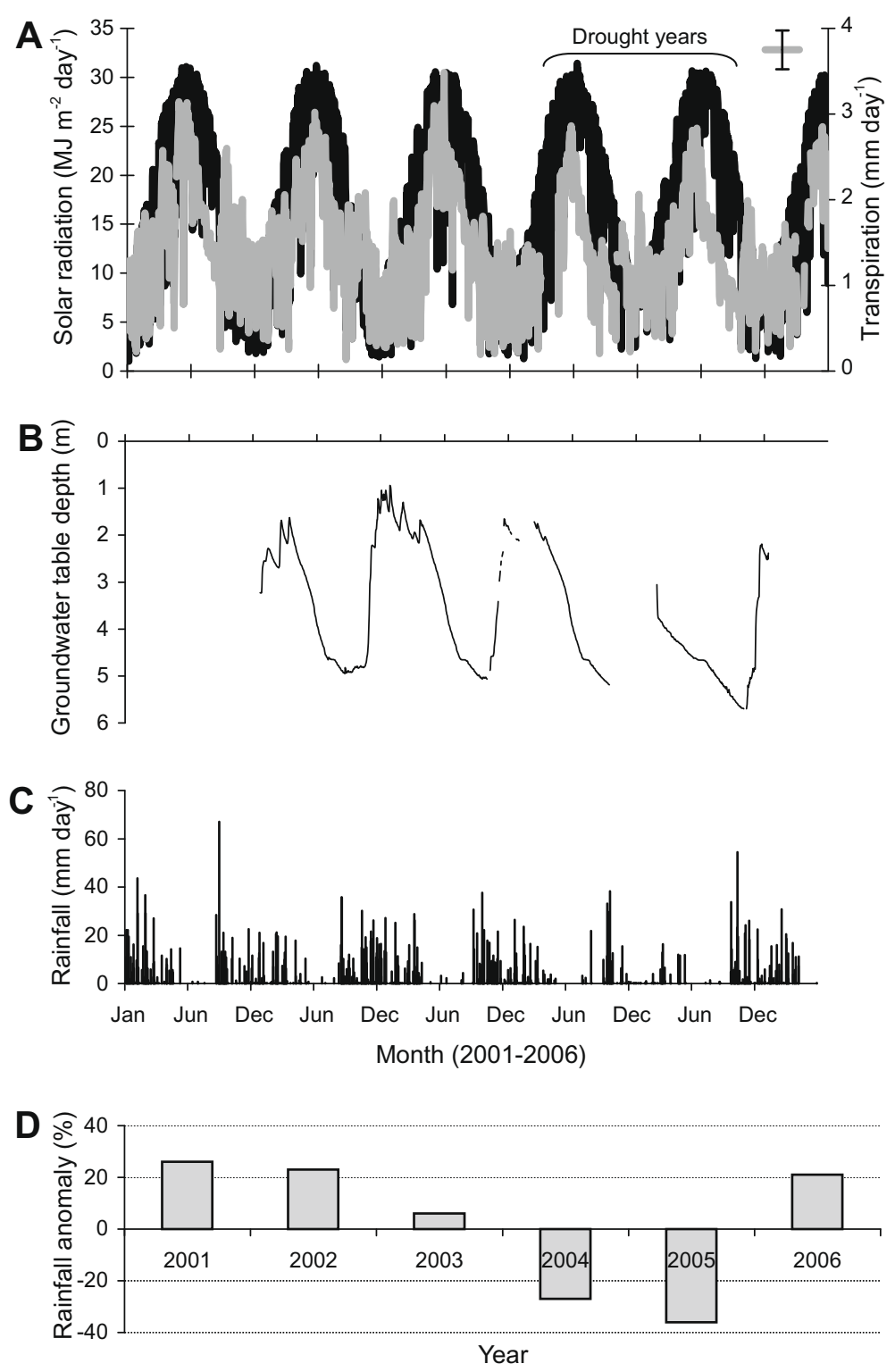

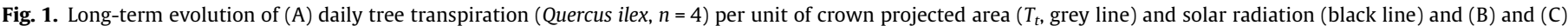

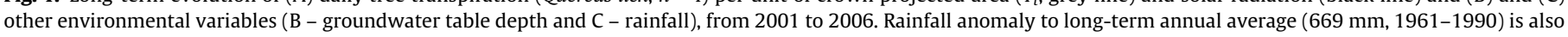
represented (D). In (A) the error bar is the average standard error of tree transpiration.

In the drought years (2004 and 2005) the maximum transpiration rate was lower and occurred earlier than in normal/wet years.

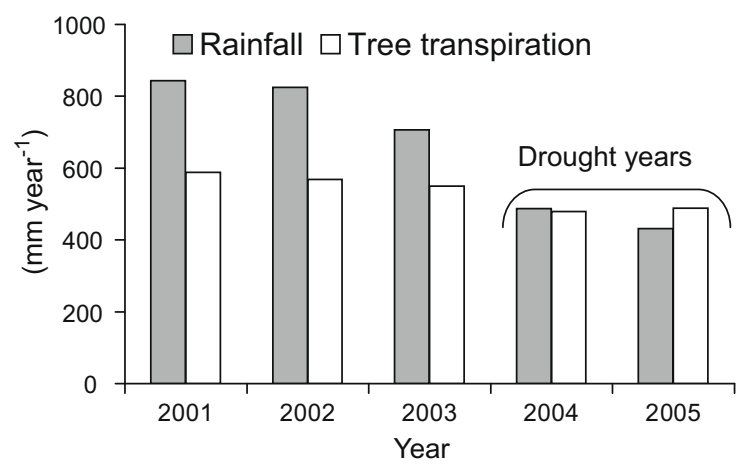

Fig. 2. Annual rainfall and tree transpiration (per unit of crown projected area) for the 2001-2005 period.
Moreover, the summer depression in transpiration lasted longer in the dry years (Fig. 1A), which means a more severe summer water stress than in normal/wet years. Nevertheless, clear sky daily tree transpiration never fell below a minimum of $0.6 \mathrm{~mm} \mathrm{day}^{-1}$ (Fig. 1A), and the drop of annual tree transpiration in the drought years was of only ca. $16 \%$ (Fig. 2). This relative decline in annual transpiration during drought was much smaller than the corresponding variation in annual rainfall (Fig. 2), evidencing a high resilience of the trees throughout the 2-year successive drought.

Fig. 2 shows that the proportion of rainwater used by the trees increases as the drought progresses, as also found by Zeppel et al. (2008). The high resilience of the trees during drought can probably be ascribed to the direct, permanent access of roots to the local groundwater reservoir. In summer 2002, stable isotope (deuterium) analyses in xylem, soil and groundwater at the site, showed that groundwater withdrawal accounted for more than $70 \%$ of total tree transpiration (David et al., 2007). This is not surprising, since it is known that evergreen trees in semi-arid environments, with seasonal drought, often rely on deep rooting and on the ability to tap 
water from permanent water tables (e.g., Walter 1973; Canadell et al., 1996; Le Maitre et al., 1999; Lubczynski and Gurwin, 2005; Schenk and Jackson, 2005; David et al., 2004, 2007), frequently showing an appreciable degree of decoupling relative to rainfall (e.g. Scott et al., 2003; Yepez et al., 2003). However, to our knowledge, this is the longest sap flow dataset ever published showing this high resilience of Mediterranean trees to prolonged drought.

Root access to groundwater will depend on tree rooting habits, water table depth and bedrock characteristics. Water table depth at our site varied between 1-2 $\mathrm{m}$ in winter and around $5 \mathrm{~m}$ in summer, in normal/wet years. Summer water table depth increased slightly during the drought, reaching a maximum of $5.8 \mathrm{~m}$ in the summer of 2005 (Fig. 1B). The hard nature of the bedrock at the experimental site (granite) probably somehow limited the development and the number of effective deep tap roots. In more fractured bedrocks, deep root development will certainly be facilitated. At a nearby site (Mitra I), where the bedrock was a fractured gneiss and water table depth around $13 \mathrm{~m}$, David et al. (2004) found a very efficient access of $Q$. ilex roots to groundwater, which allowed transpiration to follow the radiation trend all year around without any signs of summer water stress. Fig. 3 compares tree transpiration, predawn leaf water potential $\left(\Psi_{p}\right)$ and cumulative rainfall obtained during 2002 at our site (Mitra II) (David et al., 2007) to similar data for the same species (Q. ilex) collected by David et al. (2004) at the nearby Mitra I site in 1997. In both years, rainfall was higher than long-term average (54\% and $24 \%$ for 1997 and 2002, respectively), mainly due to heavy autumn rains.
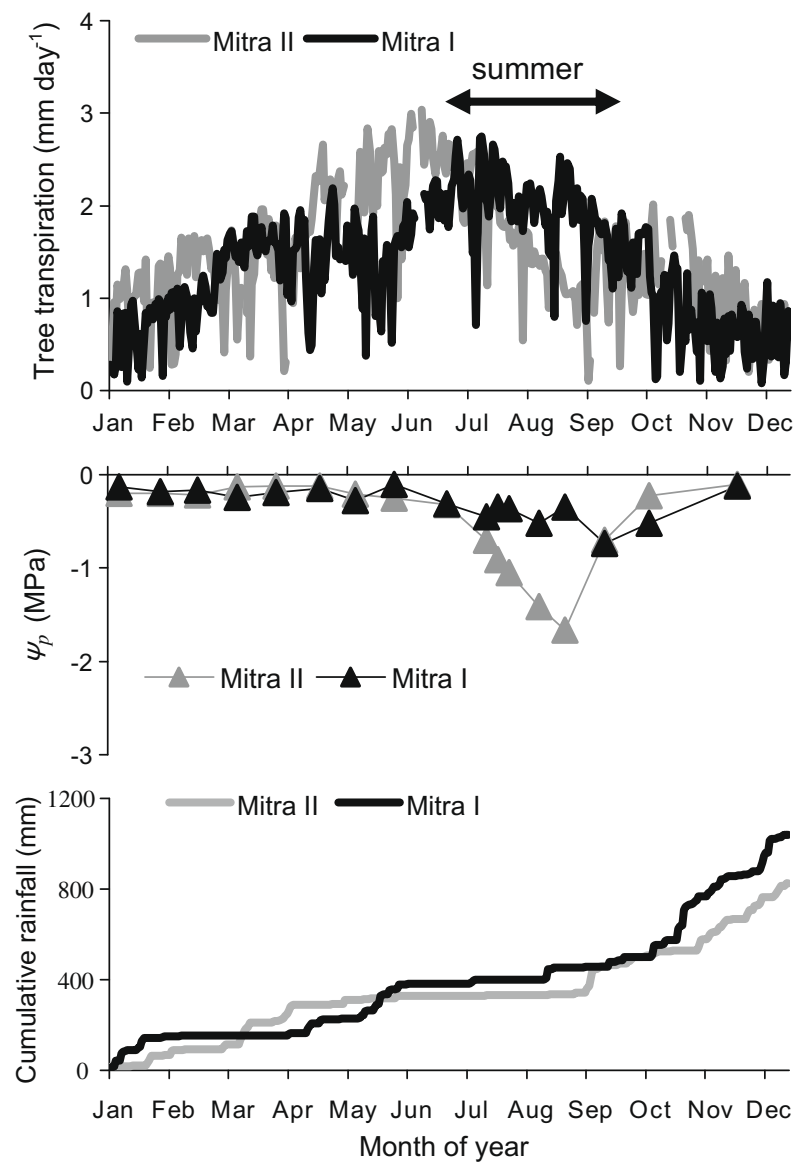

Fig. 3. Annual trends of $Q$. ilex transpiration (per unit of crown projected area), predawn leaf water potential $\left(\Psi_{p}\right)$ and cumulative rainfall evidencing different possible patterns of root groundwater uptake during summer, at two nearby sites: Mitra II, 2002 - the site under study - and Mitra I, 1997 (adapted from David et al., 2004, 2007).
Cumulative rainfall up to the end of the summer as well as summer precipitation did not differ much between the 2 years. The biggest deviation from complete similarity between the two summers was the occurrence of one isolated convective storm in 14 August 1997 in Mitra I. However, the effect of that storm on transpiration and $\Psi_{p}$ was certainly short-lived, since the low water retention capacity $(24 \mathrm{~mm})$ of the shallow soil depletes in about 8 days, at the summer rates of tree transpiration (ca. $3 \mathrm{~mm} \mathrm{day}^{-1}$ in Mitra I) (see David et al. (2004)). Therefore, we think that the differences in tree transpiration and $\Psi_{p}$ shown in Fig. 3 during the summer are mainly due to different patterns of root groundwater uptake between sites: a decrease in both tree transpiration and $\Psi_{p}$ was evident in Mitra II, but not in Mitra I. Patterns shown in Fig. 3 are typical of both sites, since they replicate in other years.

To better interpret the pattern of variation of tree transpiration in wet and dry years, canopy conductance was calculated by Eq. (1) for the months of the drying-up period (spring to summer) of the wettest (2001) and driest (2005) years of the record. Fig. 4 shows the relationships between midday canopy conductance $\left(g_{c}\right)$ and vapour pressure deficit $\left(D_{e}\right)$ for April, June, August and October of 2001 and 2005. Table 1 shows the corresponding monthly values of $g_{c}$ sensitivity to $D_{e}(m)$ and the reference $g_{c}$ at $D_{e}=1 \mathrm{kPa}(b)$, calculated from Eq. (2). For each of the examined years, the relationships in April and June were quite similar (Fig. 4), although the reference $g_{c}(b)$ and $g_{c}$ sensitivity to $D_{e}(m)$ were slightly lower in the dry year (2005) (Table 1 ). In both years, $g_{c}$ showed a significant drop during the peak of the dry season (August) (Fig. 4). However, this $g_{c}$ decrease was more pronounced in the dry year (2005)
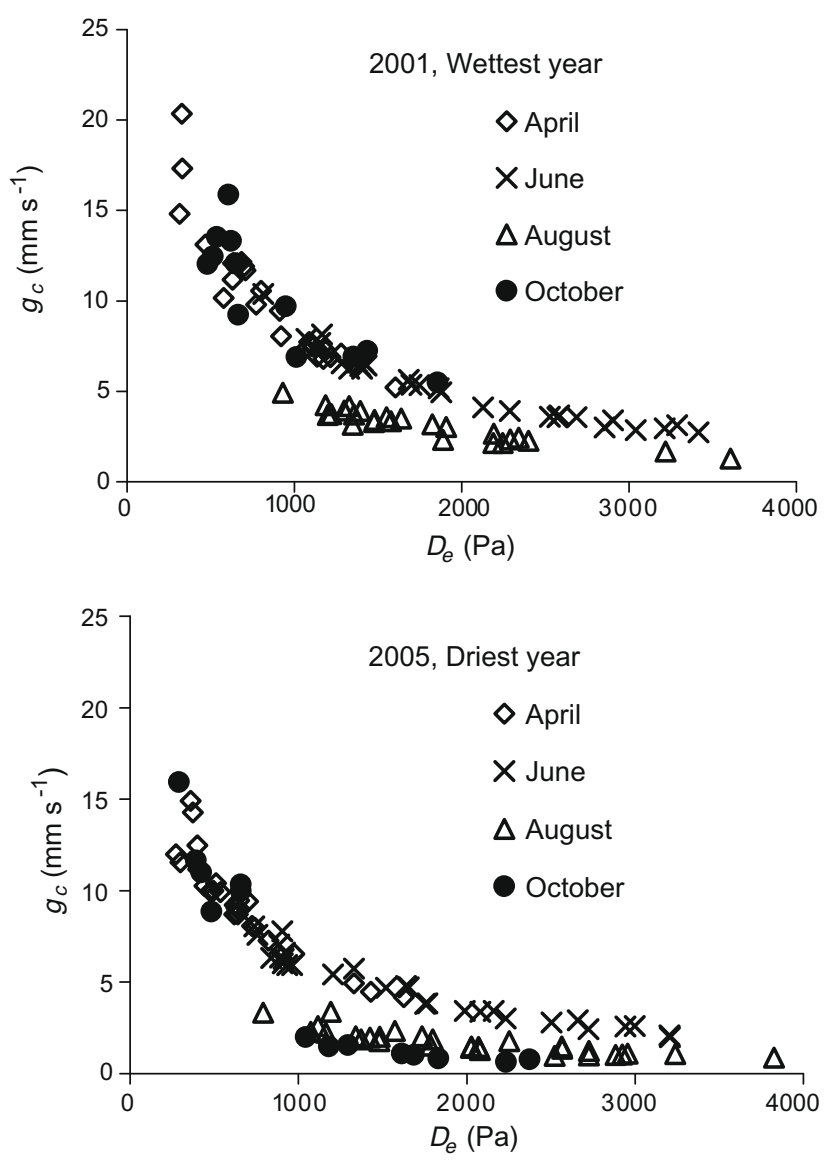

Fig. 4. Relationships between midday ( $12 \mathrm{~h}$, UT time) canopy conductance $\left(g_{c}\right)$ and vapour pressure deficit $\left(D_{e}\right)$ for selected months (April, June, August and October) during the drying-up period of the wettest (2001) and driest (2005) years of the record. 
Table 1

Values of the estimated parameters in Eq. (2) for some spring-summer months of 2001 and 2005: $m$ is the sensitivity of $g_{c}$ to $D_{e}$ and $b$ is the reference $g_{c}\left(\mathrm{~mm} \mathrm{~s}^{-1}\right)$ at $D_{e}=1 \mathrm{kPa}$. Values of the $m / b$ ratio are also shown.

\begin{tabular}{llllllll}
\hline & 2001 & & & & & 2005 & \\
\cline { 7 - 8 } & $m$ & $b$ & $m / b$ & & $m$ & $b$ & $m / b$ \\
\hline April & 7.6 & 8.4 & 0.90 & & 5.4 & 6.6 & 0.82 \\
June & 4.8 & 8.2 & 0.58 & & 3.6 & 6.2 & 0.58 \\
August & 2.6 & 4.5 & 0.58 & & 1.5 & 2.7 & 0.56 \\
October & 6.3 & 9.0 & 0.70 & & $1.5^{\mathrm{a}}$ & $1.9^{\mathrm{a}}$ & $0.79^{\mathrm{a}}$ \\
\hline
\end{tabular}

${ }^{\text {a }}$ Values prior the $g_{c}$ recovery in response to late October rain.

(Fig. 4), with lowest values of $m$ and $b$ (Table 1 ). This is in accordance with groundwater table data (Fig. 1B), which reached the lowest depth in summer of 2005.

The onset of autumn rainfall was earlier in 2001 (September) than in 2005 (late October). As a result, the $g_{c}$ vs. $D_{e}$ relationship recovered to pre-summer patterns in October 2001, but not in October 2005 (Fig. 4, Table 1). In 2005, $g_{c}$ remained low during most of October and only recovered by the end of the month, when autumn rain started (Fig. 4). At the peak of the dry season (August) the $m / b$ ratio was very similar in both years $(0.58$ in 2001 and 0.56 in 2005 ) and close to the theoretical 0.6 value, referred by Oren et al. (1999). This means that stomata were efficiently regulating leaf water potential in summer, avoiding xylem embolism, even during the peak of the drought in 2005. These results emphasize again the high resilience of the $Q$. ilex trees to severe drought. In a Spanish dehesa, Infante et al. (2003) also observed a strong stomatal regulation in $Q$. ilex, which prevented significant variations in water loss and tree water relations during prolonged drought.

\section{Tree interception loss and tree evapotranspiration}

Rainfall interception by tree canopies and subsequent evaporation loss may reach an important proportion of annual evapotranspiration. Although not measured, interception loss from the trees (I) was estimated by the tree-based adaptation of the Gash analytical model (Pereira et al., 2009a,b). Fig. 5 shows the cumulative interception loss for 2001-2005, per unit of tree crown projected area. The figure also shows the cumulative values of tree transpiration $\left(T_{t}\right.$, estimated by sap flow), tree evapotranspiration $\left(E T_{t}=\right.$ $\left.T_{t}+I\right)$ and rainfall $(P)$, during the 5-year period. Interception loss was $27 \%$ of rainfall per unit of crown projected area (or $6 \%$ of $P$ per unit of ground area) and $24 \%$ of tree evapotranspiration. These results agree well with interception loss measurements carried out in other isolated Mediterranean evergreen oaks. For instance, our estimate for the ratio of interception loss vs. rainfall (27\%) is within

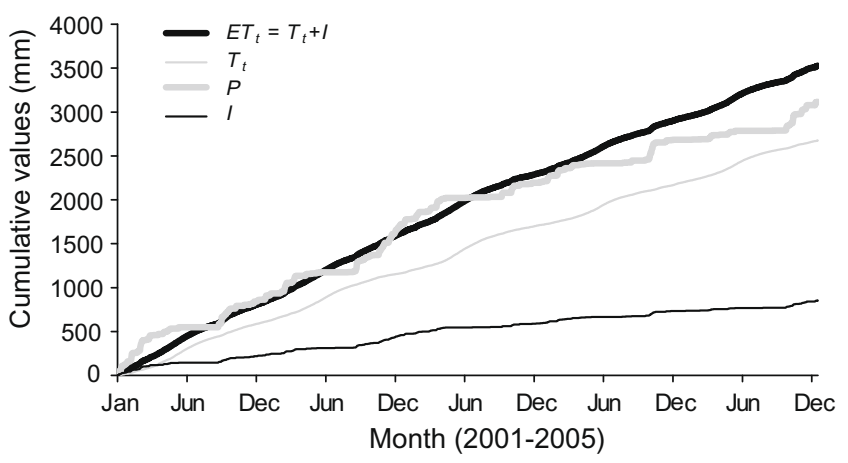

Fig. 5. Cumulative values of: $I$ - interception loss; $T_{t}$ - tree transpiration; $E T_{t}-$ tree evapotranspiration $\left(T_{t}+I\right)$ and $P$ - rainfall (2001-2005). Values are expressed per unit of crown projected area the range of measured values for Q. ilex trees (22-30\%) at nearby sites, Portugal (David et al., 2006; Pereira et al., 2009a), and for a Q. suber tree (27\%) in California (Xiao et al., 2000). Likewise, the estimate for the ratio between interception loss and total tree evapotranspiration (24\%) is close to that measured for a nearby Q. ilex tree (28\%) (David et al., 2006). This agreement is consistent with the successful model validation performed by Pereira et al. (2009a) in isolated $Q$. ilex trees and reinforces the view that the tree-based adaptation of the Gash model is adequate to properly simulate the rainfall interception process in these Mediterranean evergreen oak savannahs. Gash and Stewart (1977), McNaughton and Jarvis (1983) and Shuttleworth (1988) report that interception loss from forests may vary from $25 \%$ to $75 \%$ of overall evaporation, depending on climate and forest type. Our values, as well as those of David et al. (2006) and Pereira et al. (2009a), are close to the lower limit of this interval, probably reflecting the rainfall distribution pattern of Mediterranean climate: a relatively small number of large storms. Although interception loss is a smaller component of tree evapotranspiration than transpiration, it must be taken into account and correctly evaluated since it represents about 24-28\% of tree evapotranspiration.

Fig. 5 also shows that tree evapotranspiration $\left(E T_{t}\right)$ is higher than precipitation $(P)$ during the dry years of 2004 and 2005. This supports the earlier conclusion that deep tree roots are up taking a significant amount of water from the groundwater reservoir, causing the drop in the water table during the drought years shown in Fig. 1B.

Total ecosystem transpiration and its partitioning between trees and pasture

Fig. $6 \mathrm{~A}$ represents the patterns of evolution of daily ecosystem transpiration ( $T_{e}$, eddy covariance), tree transpiration ( $T_{t}$, sap flow) and pasture transpiration $\left(T_{p}=T_{e}-T_{t}\right)$ from February to December 2005 , for rainless days. All values are expressed in the same reference area basis: per unit of ground area. Rainfall during the winter of 2005 was very low (Fig. 6B). However, the soil at the beginning of 2005 was wet, since the previous autumn (2004) had a significant amount of rain $(237 \mathrm{~mm}$, from October to December 2004, see Fig. 1C).

Data of Fig. 6 show that pasture transpiration $\left(T_{p}\right)$ peaks in early spring (April), decreases thereafter till late spring, and stops by the beginning of July. During the summer (July-September) there is no transpiration from the pasture, and it only restarts after the onset of autumn rains (October). Tree transpiration peaks later (June), continues throughout the summer though decreasing progressively, and recovers upon autumn rainfall. During the summer drought (July-October) ecosystem transpiration equals tree transpiration, being pasture transpiration about zero. The continued transpiration of trees during summer is due to the resilience of evergreen oak trees to drought, as a result of deep rooting, as discussed above. During the dry summer season, pasture transpiration estimates show some small oscillations around an average close to zero $\left(0.003 \pm 0.08 \mathrm{~mm}\right.$ day $\left.^{-1}\right)$. Residuals (deviations from the mean) are normally distributed (Shapiro-Wilk normality test, $p$-value $=0.22)$ around a mean zero value $\left(2.8 \times 10^{-10}, t\right.$ test, $p$-value $=1$ ) (Fig. 7). Therefore, pasture transpiration during the summer can be considered as approximately zero and oscillations around that are probably due to random instrumental errors. This also suggests that eddy covariance and sap flow measurements are both correct, since they coincided during the summer.

Whereas deep rooted trees behaved largely as drought avoiders taping water from deep soil horizons or groundwater, the pasture shows a drought escaping behaviour (see Ludlow, 1989), with annual C3 herbaceous ceasing transpiration in summer when they stay in the form of seeds. Senescence of C3 herbs occurred by the 

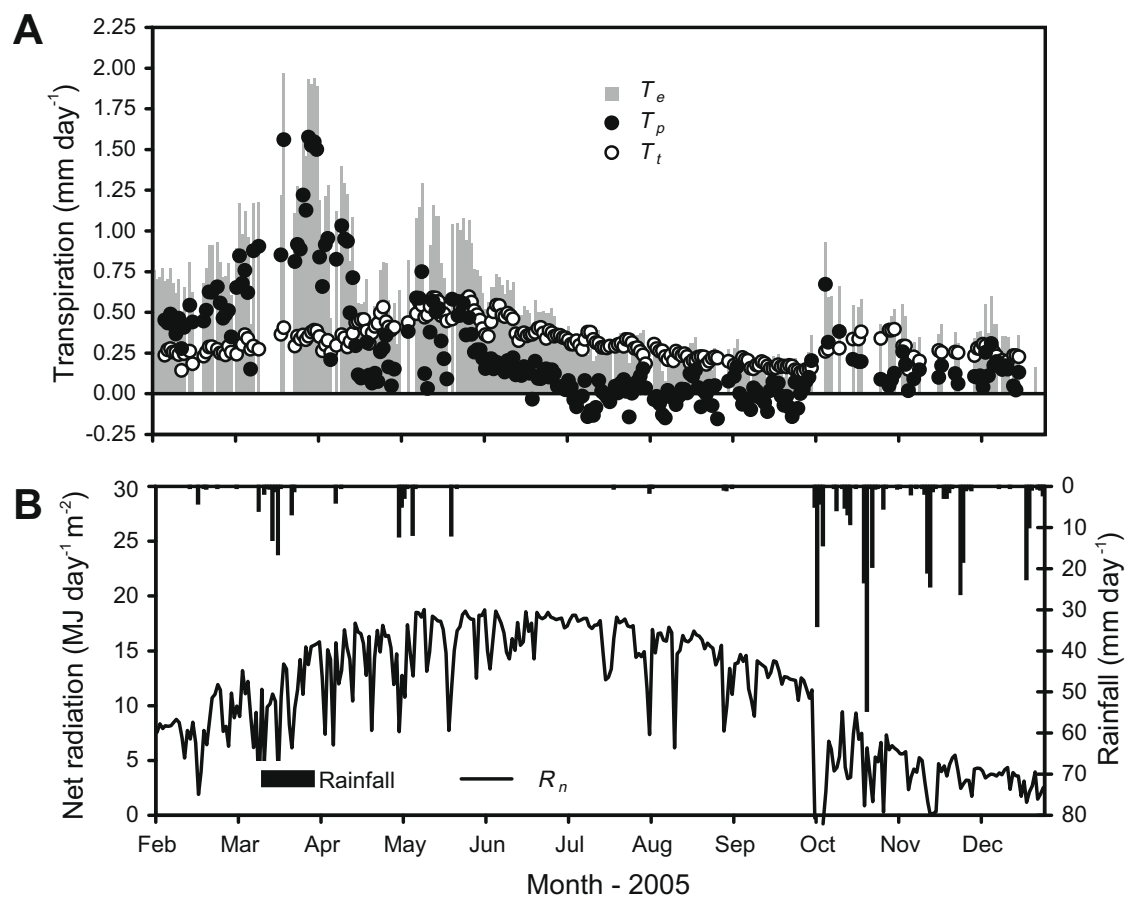

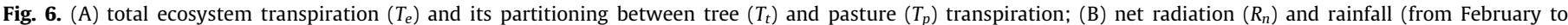
December 2005). All values are expressed per unit of ground area.
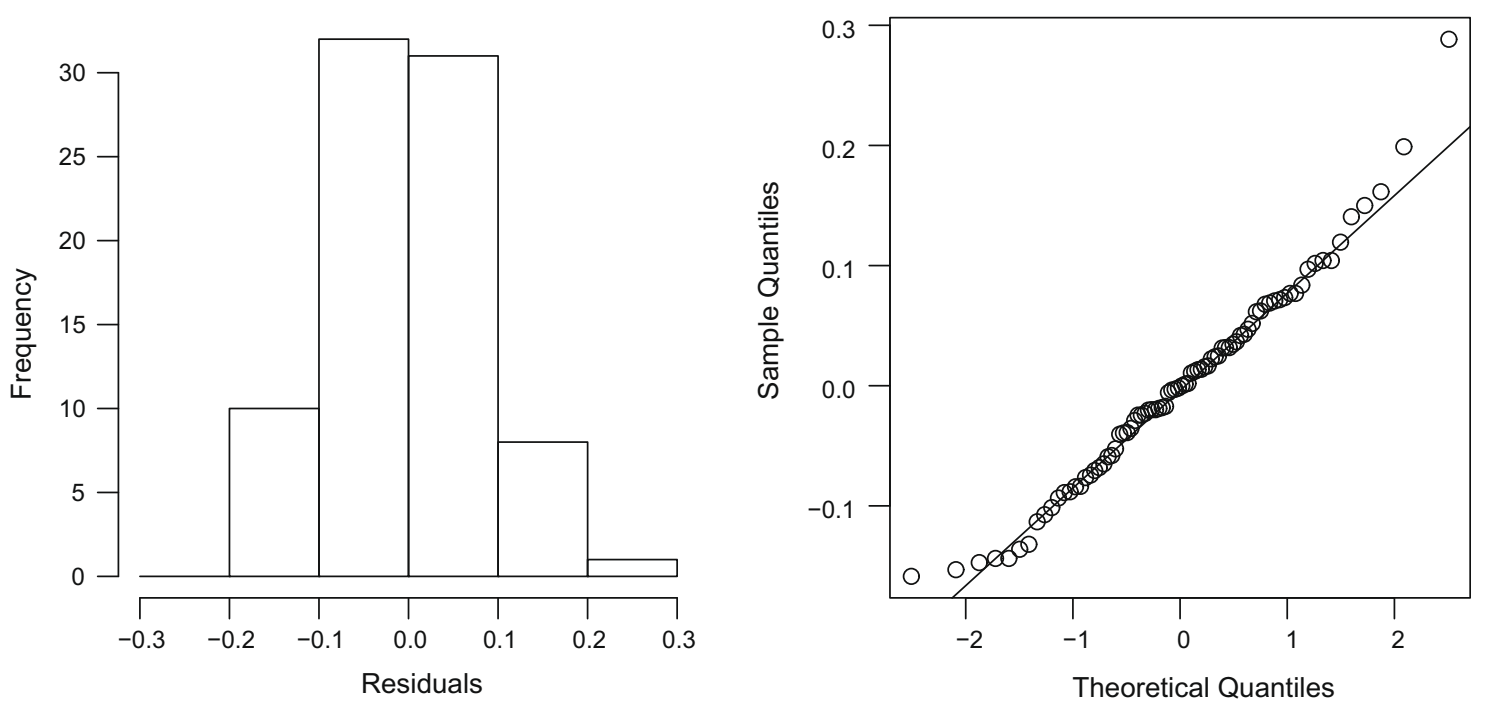

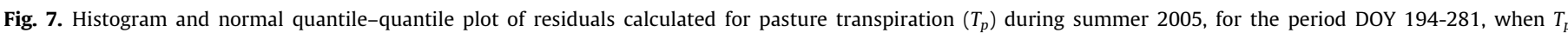
approaches zero $($ mean $=0.003$, standard deviation $=0.08)$.

beginning of May at a nearby open pasture studied by Aires et al. (2008). Pasture transpiration at our site stopped later (early July) probably due to the presence of scattered shrubs (Cistus spp.), the effect of hydraulically lifted water through tree roots (see David et al., 2007) and/or the tree shadow effect on below-crown vegetation (Joffre and Rambal, 1993; Ludwig et al., 2004). Nevertheless, the pasture seems coupled with near surface soil moisture, which depends on the occurrence of precipitation. Soil moisture content relative to field capacity (RWC) in the $0-20 \mathrm{~cm}$ soil layer was measured at the site by the gravimetric method, showing a decrease from 1 in winter to 0.1 in summer (Kurz-Besson, C. and David, T.S., 2007, personal communication). This dependence of herbaceous vegetation on top soil moisture was also found by Joffre and Rambal (1993) in Q. ilex dehesas in southern Spain and by Baldocchi et al. (2004) in annual grassland in California, who report the same in phase behaviour.

The variation in the proportions of tree and pasture transpiration relative to overall ecosystem transpiration, for spring and summer 2005, showed that in spring the two sources equilibrate, with the pasture transpiration marginally higher (54\%), but tree transpiration strongly dominates over pasture during the dry summer ( $90 \%$ and $10 \%$ of total, respectively). From February to December 2005, pasture and tree transpiration accounted for $44 \%$ and $56 \%$ of total ecosystem transpiration, respectively. The largest proportion of the ecosystem water use was, therefore, due to the trees (56\%), although they only represent $21 \%$ of the ground cover. 
Nevertheless, the contribution of pasture to total ecosystem transpiration found here (44\%) is higher than that usually reported as typical for open forests (20-30\% - Baldocchi and Xu, 2007).

Overall, our results on ecosystem flux partitioning totally agree with those obtained by Baldocchi et al. (2004) for a Californian oak savannah.

\section{Concluding remarks}

In the studied Mediterranean evergreen oak savannah, trees and pasture presented quite distinct behaviours regarding transpiration patterns. The pasture, mainly composed by annual herbs, was highly dependent on top soil water and very sensitive to summer drought: transpiration stopped in early summer. The trees were mostly dependent on deep soil and ground water, showing a high resilience to drought: transpiration continued throughout the summer, even though the canopy conductance decreased. Tree transpiration represented the highest proportion (56\%) of total ecosystem transpiration, in spite of the low tree crown cover fraction (21\%). Transpiration was the dominant component (76\%) of overall tree evapotranspiration. Interception loss from trees represented only $24 \%$ of total tree evaporation. Reinforcing the conclusions already drawn by Baldocchi et al. (2004), our results show that the correct understanding and evaluation of water use by these savannah-type ecosystems can only be based on the separate, complementary analysis of its two components: the trees and the pasture.

\section{Acknowledgements}

The authors wish to thank: FCT - Foundation for Science and Technology, Portugal, for financial support through a Post-doc fellowship for T. Afonso do Paço; the owner of Herdade da Alfarrobeira for the permission to install the experimental site; and Joaquim Mendes for help in the field work.

Projects CARBOEUROPE - IP (GOCE-CT-2003-505572) of the European Union and POCI/AGR/59152/2004 of the Portuguese Foundation for Science and Technology supported the research.

\section{References}

Aires, L.M., Pio, C.A., Pereira, J.S., 2008. The effect of drought on energy and water vapour exchange above a Mediterranean C3/C4 grassland in southern Portugal. Agricultural and Forest Meteorology 148, 565-579.

Améglio, T., Daudet, F., Archer, P., Ferreira, I., 1993. Comparaison de 3 méthodes de mesure de la transpiration de jeunes arbres. Agronomie 13, 751-759.

Baldocchi, D.D., Vogel, C.A., 1996. Energy and $\mathrm{CO}_{2}$ flux densities above and below a temperate broad-leaved forest and a boreal pine forest. Tree Physiology 16, 516.

Baldocchi, D.D., Xu, L., 2007. What limits evaporation from Mediterranean oak woodlands - the supply of moisture in the soil, physiological control by plants or the demand by the atmosphere? Advances in Water Resources 30, 21132122.

Baldocchi, D.D., Law, B.E., Anthoni, P.M., 2000. On measuring and modelling energy fluxes above the floor of a homogeneous and heterogeneous conifer forest. Agricultural and Forest Meteorology 102, 187-206.

Baldocchi, D.D., Xu, L., Kiang, N., 2004. How plant functional-type, weather, seasonal drought, and soil physical properties alter water and energy fluxes of an oakgrass savanna and an annual grassland. Agricultural and Forest Meteorology $123,13-39$.

Brunel, J.P., Walker, G.R., Dighton, J.C., Monteny, B., 1997. Use of stable isotopes of water to determine the origin of water used by the vegetation and to partition evapotranspiration. A case study from HAPEX_Sahel. Journal of Hydrology 188189, 466-481.

Canadell, J., Jackson, R.B., Ehleringer, J.R., Mooney, H.A., Sala, O.E., Schulze, E.D., 1996. Maximum rooting depth of vegetation types at the global scale. Oecologia $108,583-595$.

Carreiras, J.M., Pereira, J.M.C., Pereira, J.S., 2006. Estimation of tree canopy cover in evergreen oak woodlands using remote sensing. Forest Ecology and Management 223, 45-53.

Constantin, J., Grelle, A., Ibrom, A., Morgenstern, K., 1999. Flux partitioning between understorey and overstorey in a boreal spruce/pine forest determined by the eddy covariance method. Agricultural and Forest Meteorology 98-99, 629-643.
Daudet, F.A., 1987. Un système simple pour la mésure in situ des échanges gazeux de couverts végétaux de quelques mètres carrés de surface foliaire. Agronomie 7, 133-139.

David, T.S., Ferreira, M.I., Cohen, S., Pereira, J.S., David, J.S., 2004. Constraints on transpiration from an evergreen oak tree in southern Portugal. Agricultural and Forest Meteorology 122, 193-205.

David, J.S., Valente, F., Gash, J.H.C., 2005. Evaporation of intercepted rainfall. In: Anderson, M.G. (Ed.), Encyclopedia of Hydrological Sciences, vol. 1. John Wiley \& Sons, Ltd., Chichester, pp. 627-634.

David, T.S., Gash, J.H.C., Valente, F., Pereira, J.S., Ferreira, M.I., David, J.S., 2006. Rainfall interception by an isolated evergreen oak tree in a Mediterranean savannah. Hydrological Processes 20, 2713-2726.

David, T.S., Henriques, M.O., Kurz-Besson, C., Nunes, J., Valente, F., Vaz, M., Pereira, J.S., Siegwolf, R., Chaves, M.M., Gazarini, L.C., David, J.S., 2007. Water-use strategies in two co-occurring Mediterranean evergreen oaks: surviving the summer drought. Tree Physiology 27, 793-803.

EEA, European Environment Agency, 2007. Climate Change and Water Adaptation Issues. EEA Tecnical Report No. 2/2007, 110p.

Falk, M., Paw, U.K.T., Wharton, S., Schroeder, M., 2005. Is soil respiration a major contributor to the carbon budget within a Pacific Northwest old-growth forest? Agricultural and Forest Meteorology 135, 269-283.

FAO, 1988. FAO/UNESCO Soil Map of the World. Revised Legend, With Corrections. World Soil Resources Report 60. FAO, Rome. 119p.

Gash, J.H.C., 1979. An analytical model of rainfall interception by forests. Quarterly Journal of the Royal Meteorological Society 105, 43-55.

Gash, J.H.C., Stewart, J.B., 1977. Evaporation from Thetford forest during 1975. Journal of Hydrology 35, 385-396.

Gash, J.H.C., Lloyd, C.R., Lachaud, G., 1995. Estimating sparse forest rainfall interception with an analytical model. Journal of Hydrology 170, 79-86.

Göckede, M., Rebmann, C., Foken, T., 2004. A combination of quality assessment tools for eddy covariance measurements with footprint modelling for the characterisation of complex sites. Agricultural and Forest Meteorology 127, $175-188$.

Göckede, M., Foken, T., Aubinet, M., Aurela, M., Banza, J., Bernhofer, C., Bonnefond, J.M., Brunet, Y., Carrara, A., Clement, R., Dellwik, E., Elbers, J., Eugster, W., Fuhrer, J., Granier, A., Grünwald, T., Heinesch, B., Janssens, I.A., Knohl, A., Koeble, R., Laurila, T., Longdoz, B., Manca, G., Marek, M., Markkanen, T., Mateus, J. Matteucci, G., Mauder, M., Migliavacca, M., Minerbi, S., Moncrieff, J., Montagnani, L., Moors, E., Ourcival, J.M., Papale, D., Pereira, J., Pilegaard, K., Pita, G., Rambal, S., Rebmann, C., Rodrigues, A., Rotenberg, E., Sanz, M.J., Sedlak, P., Seufert, G., Siebicke, L., Soussana, J.F., Valentini, R., Vesala, T., Verbeeck, H., Yakir, D., 2008. Quality control of CarboEurope flux data - Part I: coupling footprint analyses with flux data quality assessment to evaluate sites in forest ecosystems. Biogeosciences 5, 433-450.

Granier, A., 1985. Une nouvelle méthode pour la mesure du flux de sève brute dans le tronc des arbres. Annales des Sciences Forestières 42, 193-200.

Granier, A., 1987. Mesure du flux de sève brute dans le tronc du Douglas par une nouvelle méthode thermique. Annales des Sciences Forestières 44, 1-14.

Hutley, L.B., O'Grady, A.P., Eamus, D., 2001. Monsoonal influences on evapotranspiration of savanna vegetation of northern Australia. Oecologia 126, 434-443.

Infante, J.M., Domingo, F., Alés, R.F., Joffre, R., Rambal, S., 2003. Quercus ilex transpiration as affected by a prolonged drought period. Biologia Plantarum 46 , 49-55.

INMG, 1991. Normais climatológicas da região de "Alentejo e Algarve", correspondentes a 1951-1980. O Clima de Portugal, Fascículo XLIX - volume 4-4a Região. INMG - Instituto Nacional de Meteorologia e Geofísica, Lisboa, 98p.

Isendahl, N., Schmidt, G., 2006. Drought in the Mediterranean: WWF policy proposals. In: WWF/Adena, WWF Mediterranean Programme, WWF Germany (Eds.), WWF - World Wide Fund for Nature Report, July 2006.

Jarvis, P.G., McNaughton, K.G., 1986. Stomatal control of transpiration: scaling up from leaf to region. In: Macfadyen, A., Ford, E.D. (Eds.), Advances in Ecological Research, vol. 15. Academic Press, London, pp. 1-49.

Joffre, R., Rambal, S., 1993. How tree cover influences the water balance of Mediterranean rangelands. Ecology 74, 570-582.

Kelliher, F.M., Lloyd, J., Arneth, A., Lühker, B., Byers, J.N., McSeveny, T.M., Milukova, I., Grigoriev, S., Panfyorov, M., Sogatchev, A., Varlargin, A., Ziegler, W., Bauer, G., Wong, S.C., Schulze, E.D., 1999. Carbon dioxide efflux density from the floor of a central Siberian pine forest. Agricultural and Forest Meteorology 94, 217232 .

Köstner, B.M.M., Schulze, E.D., Kelliher, F.M., Hollinger, D.Y., Byers, J.N., Hunt, J.E., McSeveny, T.M., Meserth, R., Weir, P.L., 1992. Transpiration and canopy conductance in a pristine broad-leaved forest of Nothofagus: an analysis of xylem sap flow and eddy correlation measurements. Oecologia 91, 350-359.

Lamaud, E., Ogée, J., Brunet, Y., Berbigier, P., 2001. Validation of eddy flux measurements above the understorey of a pine forest. Agricultural and Forest Meteorology 106, 187-203.

Lauenroth, W.K., Bradford, J.B., 2006. Ecohydrology and the partitioning AET between transpiration and evaporation in a semiarid steppe. Ecosystems 9, 756-767.

Law, B.E., Kelliher, F.M., Baldocchi, D.D., Anthoni, P.M., Irvine, J., Moore, D., Van Tuyl, S., 2001. Spatial and temporal variation in respiration in a young ponderosa pine forest during a summer drought. Agricultural and Forest Meteorology 110, 27-43.

Le Maitre, D.C., Scott, D.F., Colvin, C., 1999. A review of information on interactions between vegetation and groundwater. Water SA 25, 137-152. 
Loustau, D., Cochard, H., 1991. Utilisation d'une chambre de transpiration portable pour l'estimation de l'évapotranspiration d'un sous-bois de pin maritime à molinie (Molinia coerulea (L) Moench). Annales des Sciences Forestières 48, 2945.

Lubczynski, M.W., Gurwin, J. 2005. Integration of various data sources for transient groundwater modelling with spatio-temporally variable fluxes - Sardon study case, Spain. Journal of Hydrology 306, 71-96.

Ludlow, M.M., 1989. Strategies in response to water stress. In: Kreeb, H.K., Richter H., Hinkley, T.M. (Eds.), Structural and Functional Response to Environmental Stresses: Water Shortage. SPB Academic Press, The Netherlands, pp. 269-281.

Ludwig, F., de Kroon, H., Berendse, F., Prins, H.H.T., 2004. The influence of savanna trees on nutrient, water and light availability and the understorey vegetation. Plant Ecology 170, 93-105.

Mackay, D.S., Ahl, D.E., Ewers, B.E., Gower, S.T., Burrows, S.N., Samanta, S., Davis, K.J., 2002. Effects of aggregated classifications of forest composition on estimates of evapotranspiration in a northern Wisconsin forest. Global Change Biology 8, 1253-1265.

McNaughton, K.G., Jarvis, P.G., 1983. Predicting effects of vegetation changes on transpiration and evaporation. In: Kozlowski, T.T. (Ed.), Water Deficits and Plant Growth, vol. 7. Academic Press, Inc., New York, pp. 1-47.

Miranda, P.M.A., Valente, M.A., Tomé, A.R., Trigo, R., Coelho, M.F.E.S., Aguiar, A., Azevedo, E.B., 2006. O clima de Portugal nos séculos XX e XXI. In: Santos, F.D. Miranda, P. (Eds.), Alterações Climáticas em Portugal. Cenários, Impactes e Medidas de Adaptação. Gradiva, Lisboa, pp. 45-113.

Misson, L., Baldocchi, D.D., Black, T.A., Blanken, P.D., Brunet, Y., Curiel Yuste, J., Dorsey, J.R., Falk, M., Granier, A., Irvine, M.R., Jarosz, N., Lamaud, E., Launiainen, S., Law, B.E., Longdoz, B., Loustau, D., McKay, M., Paw, U.K.T., Vesala, T., Vickers, D., Wilson, K.B., Goldstein, A.H., 2007. Partitioning forest carbon fluxes with overstory and understory eddy-covariance measurements: a synthesis based on FLUXNET data. Agricultural and Forest Meteorology 144, 14-31.

Nadezhdina, N., Čermák, Nadezhdin, V., 1998. The heat field deformation method for sap flow measurement. In: Cérmak, J., Nadezhdina, N. (Eds.), 4th International Workshop on Measuring Sap flow in Intact Plants, Czech Republic, pp. 72-92.

Oren, R., Sperry, J.S., Katul, G.G., Pataki, D.E., Ewers, B.E., Phillips, N., Schafer, K.V.R., 1999. Survey and synthesis of intra- and inter-specific variation in stomatal sensitivity to vapour pressure deficit. Plant, Cell and Environment 22, 15151526.

Pereira, J.S., Chaves, M.M., Caldeira, M.C., Correia, A.V., 2006. Water availability and productivity. In: Morrison, J.I.L., Morecroft, D. (Eds.), Plant Growth and Climate Change. Blackwell Publishers, London, pp. 118-145.

Pereira, J.S., Mateus, J.A., Aires, L.M., Pita, G., Pio, C., David, J.S., Andrade, V., Banza, J., David, T.S., Paço, T.A., Rodrigues, A., 2007. Net ecosystem carbon exchange in three contrasting Mediterranean ecosystems - the effect of drought. Biogeosciences 4, 791-802.

Pereira, F.L., Gash, J.H.C., David, J.S., David, T.S., Monteiro, P.R., Valente, F., 2009a. Modelling interception loss from evergreen oak Mediterranean savannas: application of a tree-based modelling approach. Agricultural and Forest Meteorology 149, 680-688.

Pereira, F.L., Gash, J.H.C., David, J.S., Valente, F., 2009b. Evaporation of intercepted rainfall from isolated evergreen oak trees: do the crowns behave as wet bulbs? Agricultural and Forest Meteorology 149, 667-679.

Rutter, A.J., 1975. The hydrological cycle in vegetation. In: Montheith, J.L. (Ed.), Vegetation and the Atmosphere, vol. 1. Academic Press, London, pp. 111-154.

Schenk, H.J., Jackson, R.B., 2005. Mapping the global distribution of deep roots in relation to climate and soil characteristics. Geoderma 126, 129-140.

Scott, R.L., Watts, C., Payan, J.G., Edwards, E., Goodrich, D.C., Williams, D. Shuttleworth, W.J., 2003. The understory and overstory partitioning of energy and water fluxes in an open canopy, semiarid woodland. Agricultural and Forest Meteorology 114, 127-139.

Scott, R.L., Huxman, T.E., Cable, W.L., Emmerich, W.E., 2006. Partitioning of evapotranspiration and its relation to carbon dioxide exchange in a Chihuahuan desert shrubland. Hydrological Processes 20, 3227-3243.

Shuttleworth, W.J., 1988. Evaporation from Amazonian rainforest. In: Proceedings of the Royal Society of London, B 233. pp. 321-346.

Silva, R.M., Paço, T.A., Ferreira, M.I., Oliveira, M., 2008. Transpiration of a kiwifruit orchard estimated using the Granier sap flow method calibrated under field conditions. Acta Horticulturae 792, 593-600.

Valente, F., David, J.S., Gash, J.H.C., 1997. Modelling interception loss for two sparse eucalypt and pine forests in central Portugal using reformulated Rutter and Gash analytical models. Journal of Hydrology 190, 141-162.

Walter, H., 1973. Vegetation of the Earth. Springer-Verlag, New York. 237p.

Ward, R.C., Robinson, M., 2000. Principles of Hydrology, fourth ed. McGraw-Hill, Berkshire, England. 450p.

Williams, D.G., Cable, W., Hultine, K., Hoedjes, J.C.B., Yepez, E.A., Simonneaux, V., ErRaki, S., Boulet, G., Bruin, H.A.R., Chehbouni, A., Hartogensis, O.K., Timouk, F., 2004. Evapotranspiration components determined by stable isotope, sap flow and eddy covariance techniques. Agricultural and Forest Meteorology 125, 241258.

Wilson, K.B., Meyers, T.P., 2001. The spatial variability of energy and carbon dioxide fluxes at the floor of a deciduous forest. Boundary-Layer Meteorology 98, 443473.

Xiao, Q., McPherson, E.G., Ustin, S.L., Grismer, M.E., Simpson, J.R., 2000. Winter rainfall interception by two mature open-grown trees in Davis, California. Hydrological Processes 14, 763-784.

Yepez, E.A., Williams, D.G., Scott, R.L., Lin, G., 2003. Partitioning overstorey and understorey evapotranspiration in a semiarid savanna woodland from the isotopic composition of water vapour. Agricultural and Forest Meteorology 119 53-68.

Zeppel, M.J., Macinnis-Ng, C.M., Yunusa, I.A., Whitley, R.J., Eamus, D., 2008. Long term trends of stand transpiration in a remnant forest during wet and dry years. Journal of Hydrology 349, 200-213. 